\title{
The evolution of articulators - part I
}

\author{
Navneet Kaur Mann', Neeta Pasricha', Kavipal Singh², Navjot Singh Mann ${ }^{3}$ \\ ${ }^{1}$ National Dental College and Hospital, Derabassi, Punjab, India; \\ ${ }^{2}$ Sri Guru Ram Das Institute Of Dental Sciences And Research, Amritsar, Punjab, India; \\ ${ }^{3}$ Conservative Dentistry and Endodontics, Reader, National Dental College and Hospital, Derabassi, Punjab, India
}

\begin{abstract}
SUMMARY
One of the objectives of prosthetic dentistry is to restore teeth in harmony with temporo-mandibular joints. Articulator is a device that allows an operator to fabricate a restoration that will be physiologically and psychologically successful. But how much do we really know about the origin of articulators? First articulator designs attempted to duplicate anatomic relationships and functional movements. More sophisticated articulators evolved as more new knowledge about anatomy, mandibular movements and mechanical principles were obtained.

The aim of this article was to describe the origin, history and evolution of articulators through the years.

For this article, an electronic search was performed across three databases (Science Direct, PubMed and Google Scholar) for relevant citations. Keywords such as articulators, history, early articulators were used alone and in combination for the search. The option of "related articles" was also utilized. Finally, search was performed on the review articles and the most relevant papers were selected.
\end{abstract}

Keywords: articulators; instruments; cast; temporo-mandibular joints; hinge

\section{INTRODUCTION}

Articulators are mechanical instruments that represent maxilla, mandible and temporomandibular joints (TMJs). Their main task is to provide a frame where it is possible to relate, in the three planes of space, maxillary cast with mandibular cast relative to the hinge axis of the patient and of the instrument [1].

An articulator can be defined as following: "It is a mechanical instrument that represents temporomandibular joints and jaws, to which maxillary and mandibular casts may be attached to simulate some or all mandibular movements" [2].

Early articulators were based on individual theories of occlusion. However, normal variations in mandibular movement between patients, and even variable movement of the joints in one patient required to design adjustable articulators. The challenge for the dentist is to choose an articulator that is suitable for specific purpose. This requires an understanding of the instrument, as well as a grasp of the treatment objectives for the given patient [3].

Very little is known about the origin of dental articulators. There are two early documented facts: 1) Phillip Pfaff was the first to describe wax impression procedure and a method of making plaster casts; and 2) Jean Baptiste Gariot was the first one to describe a method for mounting casts and preserving their relationship with plaster index ("plaster articulator"). However, it must be recognized that because Gariot never claimed the procedure as an innovation, it was not associated to him. Even though "plaster articulators" were the first to be used for preserving the relationships of casts, sometime before 1840, mechanical hinge articulators have become a new and widely used device for this purpose [4]. More sophisticated articulating instruments evolved as more knoledge about anatomy, mandibular movement, and mechanical principles was obtained.

Many articles in dental literature pertaining to articulators deal with the theory and development of articulating instruments, directions for use, explanations of deficiencies and methods for overcoming them, detailed mechanical interpretations of the instruments, and various systems of classification [5].

The aim of this article was to describe the history of articulators and how they have evolved in time.

\section{MATERIAL AND METHOD}

An electronic search was performed across three databases (Science Direct, PubMed and Google Scholar) for relevant citations. Keywords such as articulators, history, early articulators were used alone and in combination for the search. The option of "related articles" was also utilized. Finally, a search was performed on the review articles and the most relevant papers pertaining to the history of articulators were selected.

Over the years some articulators have been modified, some have not been accepted by the profession and many are no longer in use [6]. Our article describes the history of articulators, beginning with the $18^{\text {th }}$ century, when the evidence of the first articulator appeared. 


\section{Plaster Articulator}

Phillip Pfaff, dentist to the court of Frederick the Great, King of Prussia, first described his method of preserving the relationship of the casts, the plaster articulator in 1756 (Figure 1) [4]. It consisted of a plaster extension on the distal portion of the mandibular cast, which was grooved to serve as a guide for plaster extension of the maxillary cast. This was the first articulator, commonly known as 'slab articulator' [5].

\section{Barn Door Hinge}

In 1805, Jean Baptiste Gariot described his method of making plaster casts and extending them posteriorly to provide an indexing mechanism for preserving the relationship of the casts [4]. The barn door hinge (Figure 2), designed by J.B.Gariot, had an anterior vertical stop. It accepted centric relation record and reproduced this position reliably [5].

\section{Hovarth and Ladmore Articulators}

The first published reference to the earliest mechanical hinge articulators is probably Fairhurst's discussion of Hovarth's articulator and Ladmore's articulator in the 1830s. Fairhurst described these and other early examples as instruments consisting of two wooden or metal blocks or slabs hinged together with a simple hinge. These articulators and others of those day must certainly have resembled what is now commonly referred to as the "barn door hinge" [7].

\section{Thomas W. Evan's Articulator}

One of the earliest mechanical hinge articulators illustrated and discussed in some detail in the literature is attributed to Thomas W Evans. In his textbook, Chapin A Harris described the T W Evans articulator as a "very simple instrument by means of which the extension of the plaster back of the plates and wax is rendered unnecessary." He emphasized that the most important feature was that vertical dimension could be preserved or altered as required. It is not known if Thomas Evans patented his Articulator. According to House, the records of the US patent office before 1870 may be incomplete. In that year, the Commissioner of Patents completely reorganized the system of keeping records and issuing patent letters. Furthermore, sometime between 1840, when the first patents were issued, and 1870, a fire destroyed many of the original patent records [7].

\section{The First US Articulator Patent - Cameron's Articulator}

The first US patent for articulator was issued to James Cameron on April 30, 1840. Cameron's articulator was unique in its departure in design from other hinge-type devices (Figure 3). There was inclusion of the anteriorposterior and vertical adjustment features [7].

\section{The Second US Articulator Patent - Even's Articulator}

The second articulator to be patented was that of Daniel T. Even (Figure 4). He first attempted to record mandibular movement and recognised the forward and lateral movement of the mandible. He named it the "Dentist's Guide". It was met with little appreciation, and consequently, disappeared from the scene. It was unsuccessful because it was inconvenient and difficult to use.[8]

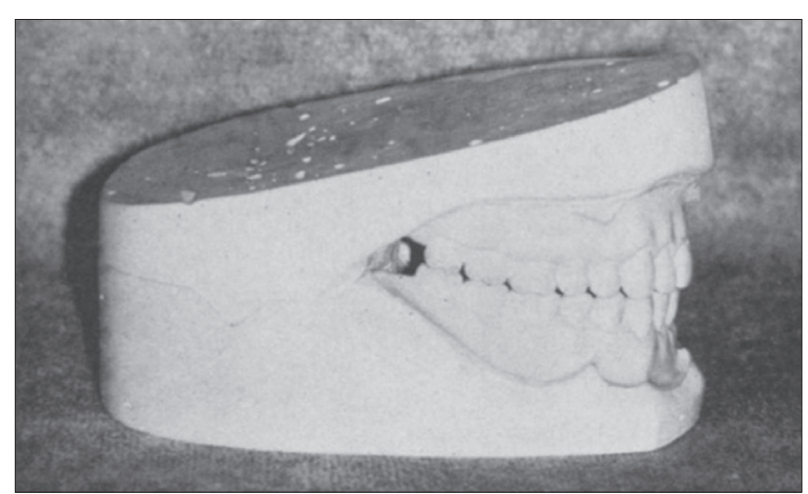

Figure 1. Plaster Articulator [5]

Slika 1. Gipsani artikulator [5]

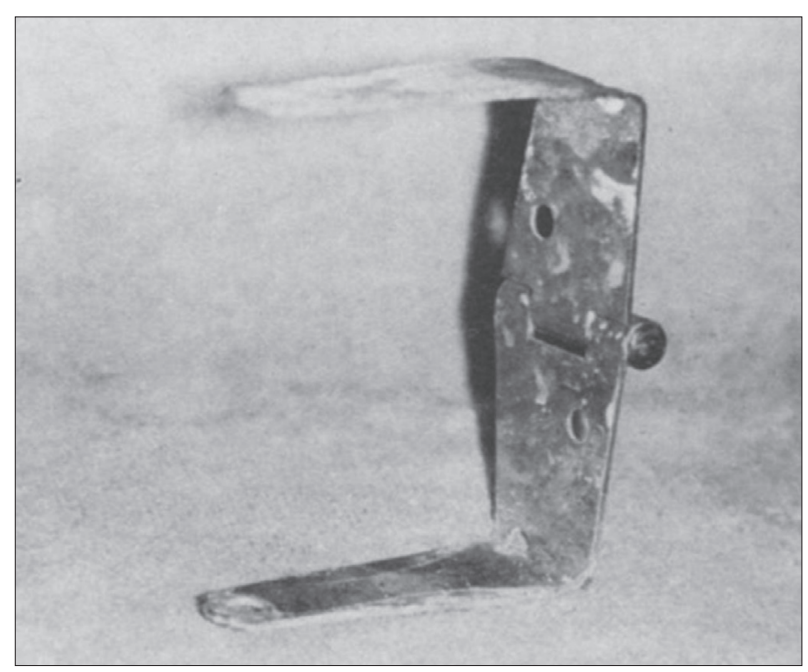

Figure 2. Barn Door Hinge [5]

Slika 2. Osovina šarnir vrata [5]

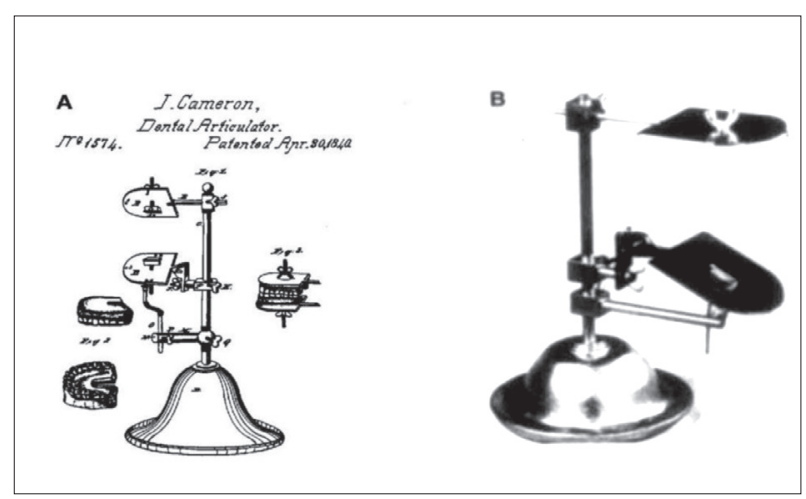

Figure 3. Cameron's Articulator [7] Slika 3. Kameronov artikulator [7] 


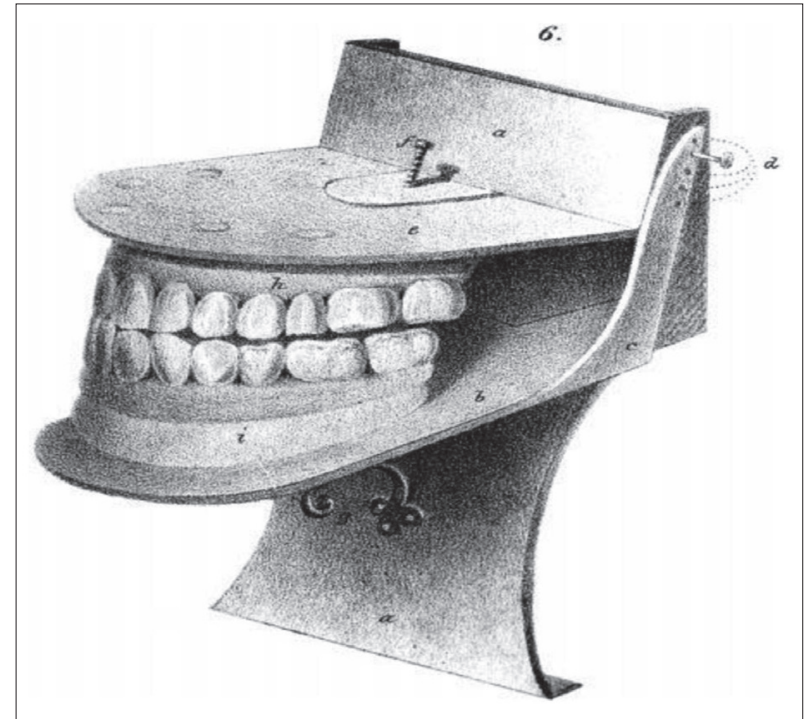

Figure 4. Even's Articulator [8]

Slika 4. Evenov artikulator [8]

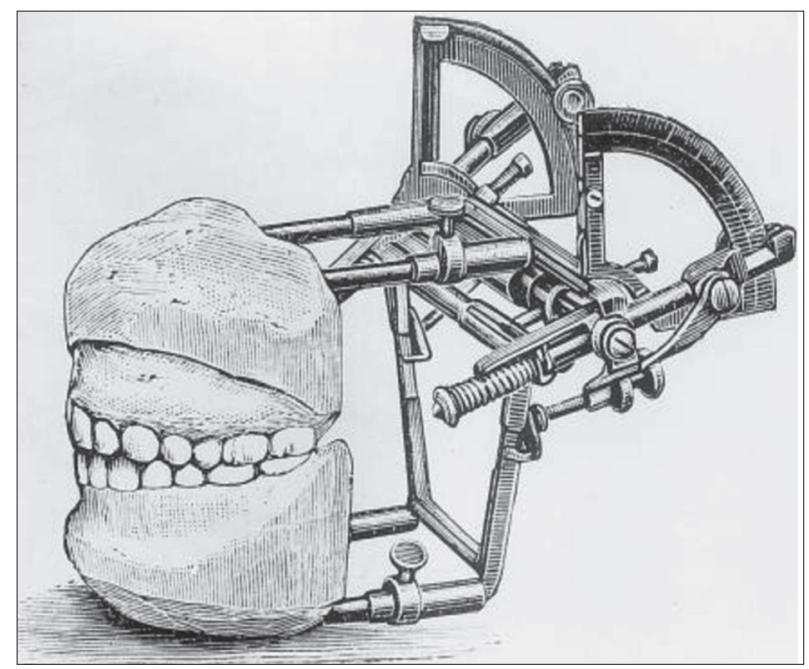

Figure 5. Walker Articulator [9]

Slika 5. Vokerov artikulator [9]

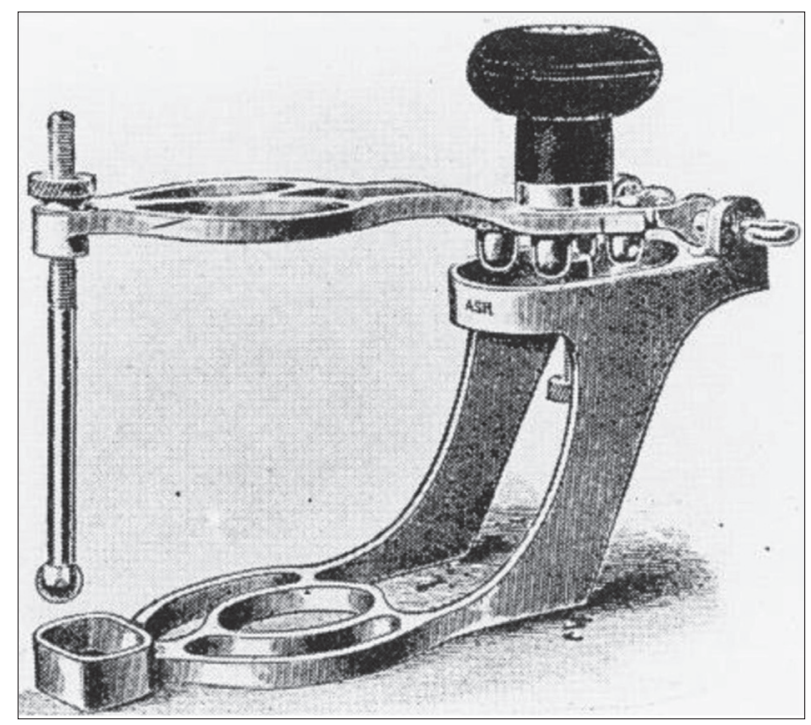

Figure 6. Luce Articulator [10]

Slika 6. Artikulator Luce [10]

\section{"Fixed Condylar Guide Articulators" And The Next Advancement}

The original Evens Articulator, with the horizontal condylar path feature, can be classified generally as a "Fixed Condylar Guide" instrument, and is the earliest of this type. Two other early patented examples were the Starr (1868), and the Antes- Lewis $(1895,1900)$. The most well-known articulator in this category was the Bonwill (1858). All of these articulators received some acceptance by the profession. Indeed, the Bonwill was popular for many years. But none represented a further innovation in principle. It was not until almost 50 years after the Evens was patented that Richmond S. Hayes would incorporate the next important advancement into an articulator, the downward and forward condylar path, when he issued a patent for his "fixed condylar guide" instrument in 1889 [8].

\section{The First “Adjustable Condylar Guide" Articulator}

The next important breakthrough in articulator design occurred in 1896, when William E. Walker of Pass Christian, MS obtained 2 patents for articulators with adjustable condylar guides (Figure 5). The earliest version of his articulator, constructed in about 1895 , had fixed condylar guides. Although the second model, featured adjustable condylar controls, they could not be set individually. The third model of the Walker articulator was the first to include individually adjustable condylar guides as well as adjustable rotation centers for lateral movement. Walker patented these last 2 models sequentially, calling them "Walker's Physiological Articulators". To measure the path of each condyle individually Walker designed an apparatus that he called "facial clinometer" and procedure for its use. Because it was designed to determine the angle of the condylar paths on the face, it can be considered first extraoral method for recording mandibular movement, although the paths were not actually scribed. Facial clinometer was never patented [9].

\section{The Appearance And Early Use Of The Incisal-Pin And Guide [10]}

As early as the 1840 s, some form of "vertical stop" was common component of mechanical articulators. Clearly, some early inventors recognized the importance of preserving vertical relationship of the casts in the articulator and provided this feature.

\section{The First Articulators Patented With An Incisal- Pin And Guide Assembly}

C.E. Luce, of Stuttgart, Germany, received the first patent for an articulator with an incisal-pin and guide assembly on November 28, 1911. Luce was also one of the first investigators to describe downward and forward movements of condyles (1889). Luce's articulator was the first "scribing" type; that is, it had posterior and incisal path controls that were functionally generated (Figure 6). 


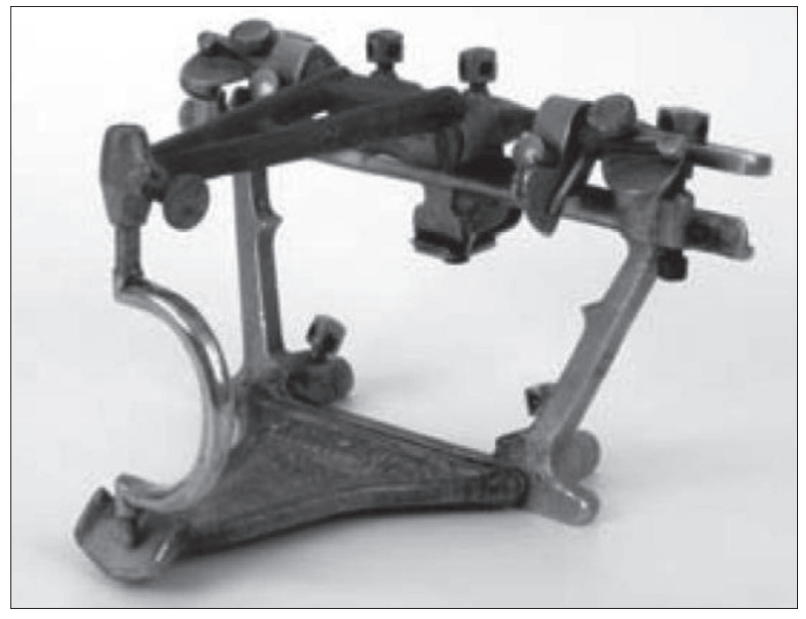

Figure 7. Gysi's Adaptable Instrument [10] Slika 7. Gysijev adaptabilni instrument [10]

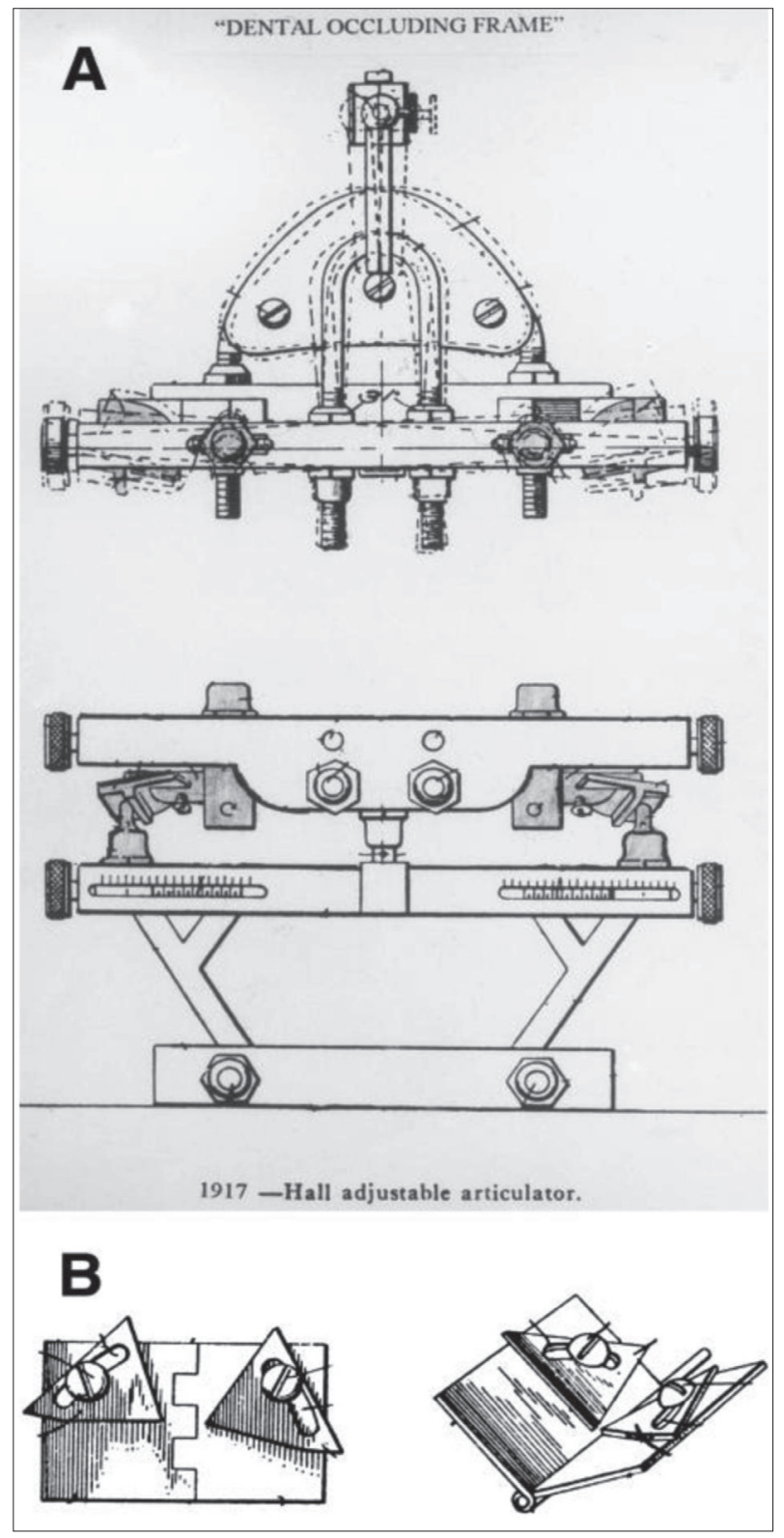

Figure 8. Hall's Occluding Instrument [10]

Slika 8. Holov okludirajući instrument [10]
The second patent issued for an articulator with this feature was received by Ernest Eltner of Basel, Switzerland in July 1912. Eltner's articulator featured horizontal incisal guide table with adjustable posterior vertical flange that limited protrusive movements. The incisal pin had a chevron-shaped blade tip.

Alfred Gysi received a patent for his "Adaptable" articulator in October 1912 (Figure 7). This was Gysi’s first US articulator patent. Although the "Adaptable" was highly advanced for the time, it had only fixed, 45-degree incisal guide table. Nevertheless, the "Adaptable" was considered too complicated for the average practitioner and did not achieve commercial success. Gysi used the exact incisal guide design in his "Simplex" articulator, an "average value" version of the "Adaptable" articulator.

Ray W. Burch of Hart, MI received the fourth patent issued for an articulator with incisal pin, in December 1913. Burch was the first to employ the innovation of converting maxillary and mandibular facebows into an articulator. The facebow devices were connected by condylar slot assemblies and were adjusted while being worn by the patient. The incisal pin was used simply to maintain the anterior vertical position.

After the Burch articulator, George B. Snow patented the "Acme" articulator in November 1915, which was Snow's third articulator patent and the first with incisalpin and guide. In the earliest model, the protrusive angle of the incisal table was adjusted by heating the solder between the components identified by the numbers 4 and 8 , and moving the table up or down. Later models featured interchangeable tables, and finally, an adjustable table with a setscrew.

David M. Shaw of Eltham, England, patented an articulator in February 1916. This device has been largely overlooked, but deserves mentioning due to the notable design of the incisal pin assembly, apparently intended to affect protrusive and lateral motion with the curved incisal chevron-shaped tip functioning on the curved wire "guide."

In November 1916, Rupert E. Hall received his first patent for an articulator, a device that has been unceremoniously nicknamed "Alligator". The "Alligator" was the first articulator to include an incisal guide table with adjustable lateral wings. On Hall's second articulator (March 1917), a revised version of the "Alligator," the incisal pin was designed to function within a 45 -degree cup.

\section{Hall's "Dental Occluding Frame": The First Patented Gothic Arch Incisal Guide Table}

Rupert Hall's third articulator patent, issued for "Dental Occluding Frame" (April 1917), was groundbreaking (Figure 8). It was an arcon instrument that featured adjustable, curved condylar paths, including settings for the BalkwillBennett angle, and a mechanism for adjusting the intercondylar distance. It also included horizontal incisal table with adjustable lateral wings, as well as new feature - a triangular guiding edge on each lateral wing that could be set to follow "gothic arch" tracing. 


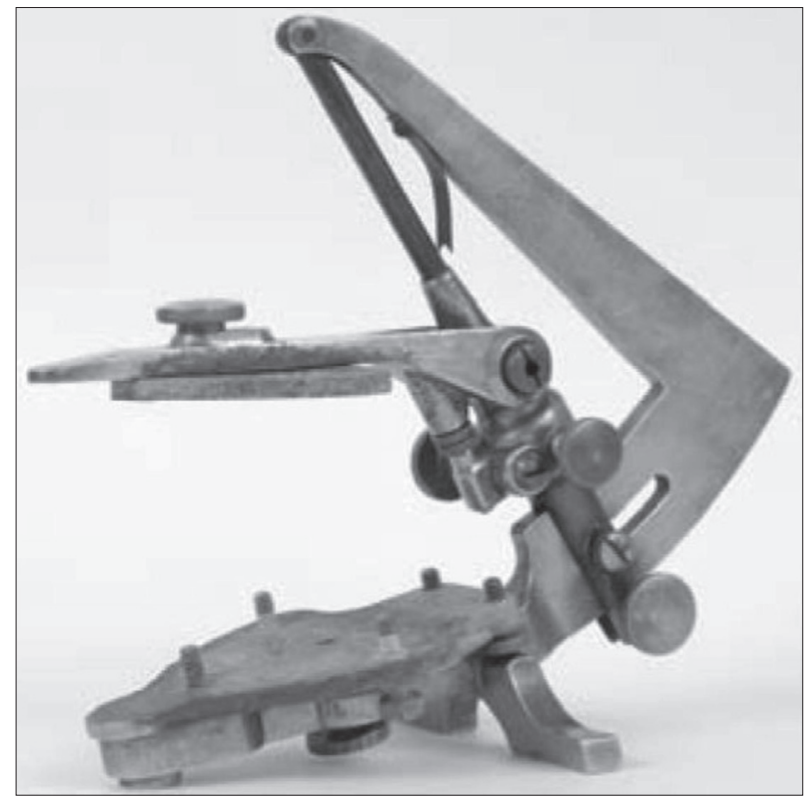

Figure 9. Maxillomandibular Instrument [5] Slika 9. Maksilomandibularni instrument [5]

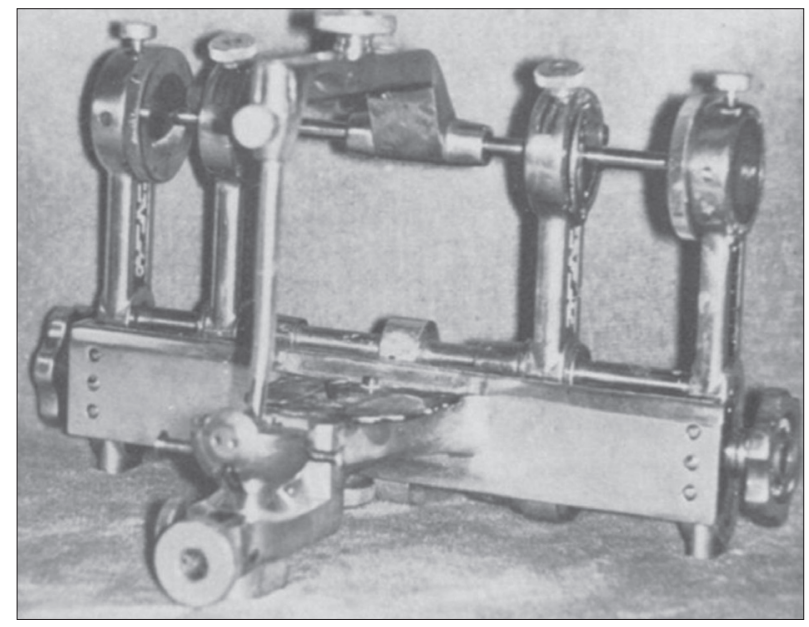

Figure 10. Hanau Model M Kinescope [5]

Slika 10. Kinetoskop Hanau Model M [5]

\section{Maxillomandibular Instrument}

It was designed by George Monson in 1918, and was based on the spherical theory. According to this theory, which evolved from the concepts of Monson and a German anatomist Graf von Spee, the mandibular teeth move over the maxillary teeth as over the surface of a sphere. The average radius of the sphere is 4 inches, but the Monson instrument has set screws that can vary the instrument's radius (Figure 9) [5].

\section{Stephen Articulator}

Stephen articulator, developed in 1921, is similar in design to the Gariot hinge articulator from 1805, except that it has a fixed condylar inclination and allows for an arbitrary lateral movement. A posterior set screw holds the upper and lower members of the articulator at fixed vertical dimension [5].

\section{The Hanau Model C Articulator And The Hanau Model M Kinoscope}

Rudolph L. Hanau, an engineer, was influenced by Dr. Rupert E. Hall to study the design of articulators. Early in 1921 he developed a research model called the Hanau Model C articulator. In 1923, he developed another research instrument, the Hanau Model M Kinoscope articulator (Figure 10). It has double condylar posts on each side. The inner posts serve two purposes- (1) they act as the horizontal condylar guides and (2) they are variable rotation centers when the posts are moved inward or outward. The Bennett angle is adjusted by rotating an eccentric cone located on the outer posts against the intercondylar axis [5].

\section{Homer Relator}

Homer Relator was introduced in 1923 by Joseph Homer. It was based on a principle that plastic material rather than mechanical guides is used to preserve articulator positions. Three cups in the lower member filled with plastic material (usually modeling compound), capture the record and guide the tripoded upper member into the recorded positions. The same principle has been used later in the Irish duplifunctional and TMJ instruments [5].

\section{Wadsworth Articulator}

Wadsworth believed in Monson's spherical theory but he could not accept bilateral condylar symmetry. In the Wadsworth articulator, developed in 1924, the casts were mounted with a facebow and the Wadsworth T-attachment determined the third point of reference. A divider was used to measure the distance from the median incisal point to the condyle center on one side. This arc length was described first from the condyle and then from the median incisal point to the flag located on the instrument's upper member. The intersection of these arcs was located on the rotational center for the measured side. The center was used to design a spherical plane of occlusion. It had an adjustable intercondylar distance as well. This measurement was determined by using the distance between the facebow condyle pointers minus 0.75 inch skin-condyle distance on each side. The condylar paths of the instrument were slightly curved [5].

\section{The Hanau Model H110}

The Hanau Model H110 was introduced by Hanau in 1926 and was designed primarily for complete denture and to encompass mechanical averages of many previous concepts. It has individual condylar guidance adjustments in both sagittal and horinzontal planes [5]. Rather than using lateral positional records, the lateral setting was calculated using the formula, given at the base of the articulator:

$$
\mathrm{L}=\mathrm{H} / 8+12 \text {, where } \mathrm{H}=\text { Horizontal condylar angle. }
$$




\section{The Hanau Model H110 Modified}

It was designed in 1927, and introduced the incisal guide table. The original incisal guide cup with its fixed curvature could be moved only as a unit, and it did not have calibrations for resetting. The improved table appeared on Hanau articulators from 1927 to 1972 and allowed for adjustments in three dimensions through considerable range [5].

\section{The Hagman Balancer}

Developed in 1920s by H. C. Hagman, the Hagman Balancer opens and closes on a hinge that is in the center of the upright support but requires no facebow or interocclusal records for mounting. A centering device transfers maxillary and mandibular impressions form the patient to the articulator in one step. It was also based on spherical theory of occlusion. Mandibular teeth are constructed to the curve of Spee using a balanced occlusal guide, and maxillary teeth are constructed to fit with mandibular teeth [5].

\section{Phillips Student Articulator}

The Phillips Student articulator (Model C), or the Pantographic articulator, was developed by George P. Phillips in 1926 (Figure 11). This articulator is classified as fully adaptable, as its developer claimed that it would follow any graphic record. The Phillips graphic recorder was designed to trace in one step the Gothic arch (needlepoint) tracing and the inclinations of glenoid fossa. The articulator could reproduce mechanically the movements of the graphic recorder through the use of two vertical pins that follow horizontal inclination of glenoid fossa, and two horizontal pins that retraced needle point tracing [5].

\section{Stanbery Tripod Instrument}

Developed in 1929 by C. J. Stansbery, this articulator was designed without a hinge to facilitate the reproduction of any positional relationship. There is no mechanical equivalent or representation of condyles. The articulator reproduces positions, not movements. Interocclusal positional records of centric, protrusive, right lateral and left

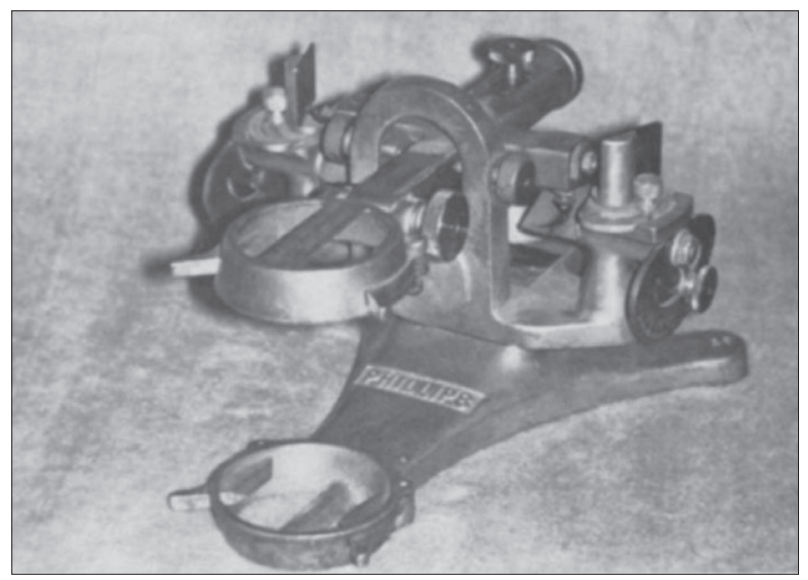

Figure 11. Phillip's Student Articulator [5]

Slika 11. Filips Studentov artikulator [5] lateral positions are used to set three individual turrets and slots of the tripod, with the slots forming straight line to the centric position [5].

\section{House Articulator}

The House articulator was developed by M. M. House in early 1930s. The Needle-House intraoral chew-in or other positional records were used to set the House articulator. The intercondylar centers of rotation varied without moving the lateral posts that support the condylar elements, with the help of hooks that could slide along the intercondylar bar. The lateral condylar guidance was controlled by the Bennett guide, attached lateral to the condylar guide slot. The incisal guide table could control horizontal and vertical movement. Lateral plates in the guide table created a mechanical function as a curved incisal pin [5].

\section{Precision Coordinator}

The Precision Coordinator was developed by W. H. Terrell in the early 1930s. It is an arcon type of articulator that has curvilinear condylar guides. Twin parabolic cams control vertical and horizontal anterior guidance. The incisal pin is curved to allow for changes in the vertical dimension. There is also freedom of movement in centric relation [5].

\section{The Hanau Crown And Bridge Articulator}

The Hanau Crown and Bridge articulator 29-0 was manufactured by the Hanau Engineering Co from 1934 to 1971. It is a small articulator. A posterior pin-and-cam guidance mechanism can be set to simulate working and balancing side excursions of 15 degrees. The mechanism can be set to $\mathrm{L}$ for restorations in patient's left quadrant, $\mathrm{R}$ for right quadrant, or Anterior restorations or for equalizing right and left excursions. Its protrusive movements were up to 30 degrees. No facebow was needed [5].

\section{The Philips Occlusoscope}

The Philips Occlusoscope articulator was developed by George P. Phillips in 1938. The maxillary cast on the The Philips Occlusoscope articulator was mounted with the use of a facebow. The articulator could be adjusted by either intraoral or extraoral records. The lower member had two adjustable units that represents the two tempormandibular joints. Within each adjustable unit, there was a circular disc that could be tilted anteroposteriorly and laterally. It did not have an adjustable incisal guide. The incisal pin rested on a flat plane because Philips believed that an incisal guide pin serves only to prevent closure and should not serve as a third tempomandibular joint [5].

\section{CONCLUSION}

Articulators are instruments that attempt to reproduce the range of movement of the jaw. The first instrument designs attempted to duplicate anatomic relationships or 
reproduce functional movements of the anatomy. More sophisticated articulating instruments evolved as more was learned about anatomy, mandibular movements, and mechanical principles. However, the objective was always same: to produce or reproduce occlusal relationships extraorally. No matter how simple or complicated an articulator may be, if the operator does not use it properly or if it does not have the features for the basic purpose for which is used, the results will be disappointing [3]. A history of articulators since 1940 will be published in the next part of the article.

\section{REFERENCES}

1. Winkler S. Essentials of complete denture prosthodontics, $2^{\text {nd }}$ Indian edn. AITBS Publishers. 2009; 142-3.

2. Glossary Of Prosthodontic Terms. J Prosthet Dent. 2005; 94:10-92.
3. Zarb GA, Bolender CL. Prosthodontic Treatment For The Edentulous Patient, $12^{\text {th }}$ edn. St Louis: C.V. Mosby; 2004; 291-2.

4. Starcke Edgar N. The history of articulators: A perspective on the early years, Part I.J Prosthodont. 1999; 8:209-11.

5. Mitchell DL, Wilkie ND. Articulators through the years. Part I.J Prosthet Dent. 1978; 39:330-8.

6. Mitchell DL, Wilkie ND. Articulators through the years. Part II. J Prosthet Dent. 1978; 39:451-8.

7. Starcke Edgar N. The history of articulators: A perspective on the early years, Part II. J Prosthodont. 1999; 8:277-80.

8. Starcke Edgar N. The history of articulators: Early attempts to reproduce mandibular movement. J Prosthodont. 2000; 9:51-6.

9. Starcke Edgar N. The history of articulators: Early attempts to reproduce mandibular movement, Part III. J Prosthodont. 2000; 9:217-22.

10. Starcke Edgar N. The history of articulators: The appearance and early use of the incisal pin and guide. J Prosthodont. 2001; 10:52-60.

Received: 26.05.2017 • Accepted: 08.08.2017 


\title{
Istorija artikulatora - prvi deo
}

\author{
Navnit Kaur Man ${ }^{1}$, Nita Pasriča ${ }^{1}$, Kavipal Sing ${ }^{2}$, Navdžot Sing Man ${ }^{3}$ \\ ${ }^{1}$ Nacionalni stomatološki fakultet i bolnica, Dera Basi, Pandžab, Indija; \\ 2Institut za stomatološke nauke i istraživanje „Sri Guru Ram Das", Amricar, Pandžab, Indija; \\ ${ }^{3}$ Katedra za konzervativnu stomatologiju i endodonciju, Čitatelj, Nacionalna stomatološki fakultet i bolnica, Dera Basi, Pandžab, Indija
}

\begin{abstract}
KRATAK SADRŽAJ
Jedan od ciljeva stomatološke protetike je da protetske nadoknade zuba uradi u skladu sa temporomandibularnim zglobovima. Artikulator je uređaj koji omogućava stomatologu da proizvede protetsku nadoknadu koja će biti fiziološki i psihološki uspešna. Ali koliko znamo o poreklu artikulatora? Prvi dizajni artikulatora imali su za cilj da dupliraju anatomske odnose i funkcionalne pokrete. Sofisticiraniji artikulatori nastali su zahvaljujući novim saznanjima o anatomiji, pokretima donje vilice i mehaničkim principima. Cilj ovog rada bio je da opiše poreklo, istoriju i evoluciju artikulatora.

Izvršena je elektronska pretraga u tri baze podataka (Science Direct, PubMed i Google Scholar) za relevantne citate. Ključne reči kao što su artikulatori, istorija i rani artikulatori su korišćene same ili u kombinaciji. Korišćena je i opcija „povezanih članaka“. Na kraju, izvršena je pretraga revijalnih radova i odabrani su najrelevantniji radovi.

Ključne reči: artikulatori; instrumenti; gipsani modeli; temporomandibularni zglobovi; osovina
\end{abstract}

\section{UVOD}

Artikulatori su mehanički instrumenti koji simuliraju gornju i donju vilicu i temporomandibularne zglobove (TMZ). Njihov glavni zadatak je da obezbede okvir u kome je moguće, u tri ravni, upostaviti odnos gipsanih modela gornje i donje vilice u odnosu na osu zgloba pacijenta i instrumenta [1]. Artikulator se može definisati na sledeći način: „To je mehanički instrument koji predstavlja temporomandibularne zglobove i vilice, na koji se mogu pričvrstiti gornji i donji gipsani modeli vilice i koji simuliraju neke ili sve pokrete donje vilice" [2]. Rani artikulatori su bazirani na individualnim teorijama okluzije. Međutim, normalne varijacije kretnji donje vilice kod različitih pacijenata, pa čak i varijabilno kretanje zglobova kod jednog pacijenta, zahtevalo je dizajniranje prilagodljivih artikulatora. Izazov za stomatologa je izbor artikulatora koji je pogodan za specifičnu svrhu. Ovo zahteva razumevanje instrumenta, kao i razumevanje ciljeva tretmana datog pacijenta [3].

Veoma malo se zna o poreklu artikulatora. Postoje dve ranije dokumentovane činjenice: 1) Phillip Pfaff je prvi koji je opisao postupak uzimanja zubnih otisaka u vosku i izradu gipsanih modela i 2) Jean Baptiste Gariot je bio prvi koji je opisao metod za montažu gipsanih odela i očuvanje njihovog odnosa pomoću gipsanog indeksa („gipsani artikulator“). Međutim, s obzirom na to da Gariot nikada nije patentirao svoj postupak, on se i ne vezuje za njega. Iako su ,gipsani artikulatori“ bili prvi koji su se koristili za očuvanje odnosa gipsanih modela, negde pre 1840. godine, artikulatori sa mehaničkim osovinama su postali novi i široko upotrebljivani aparati za tu svrhu [4]. Sofisticiraniji artikulatori razvijeni su zahvaljujući novim saznanjima o anatomiji, pokretima donje vilice i mehaničkim principima.

Mnogi članci u stomatološkoj literaturi koji se odnose na artikulatore bave se teorijom i razvojem artikulacionih instrumenata, uputstvima za upotrebu, objašnjenjima nedostataka i metoda za njihovo prevazilaženje, detaljnim mehaničkim interpretacijama instrumenata i različitih sistema klasifikacije [5].

Cilj našeg rada bio je opisati istoriju artikulatora i njihov razvoj i usavršavanje.

\section{MATERIJAL I METOD}

Elektronska pretraga obavljena je kroz tri baze podataka (Science Direct, PubMed i Google Scholar) za relevantne citate. Ključne reči kao što su artikulatori, istorija, rani artikulatori korišćene su same ili u kombinaciji za pretraživanje. Korišćena je i opcija „povezanih članaka“. Konačno, izvršena je pretraga revijalnih radova i izabrani su najvažniji citati koji se odnose na istoriju artikulatora.

Tokom godina su neki artikulatori modifikovani, neki od njih nisu prihvaćeni od strane profesije i mnogi se više ne koriste [6]. Naš rad opisuje istoriju artikulatora sve od 18. veka, kada su se pojavili dokazi prvog artikulatora.

\section{Gips Artikulator}

Phillip Pfaff, stomatolog suda Fridriha Velikog, kralja Pruske, prvi opisao svoj metod očuvanja odnosa gipsanih modela vilica pomoću gipsanih artikulatora 1756. god. (Slika 1) [4]. On se sastojao od gipsanog proširenja na zadnjem delu gipsanog modela donje vilice, koji je izgledao kao žleb i služio kao vodič za gipsano proširenje modela gornje vilice. Ovo je bio prvi artikulator, poznat kao „pločani artikulator“ [5].

\section{Osovina šarnir vrata (Barn Door Hinge)}

Godine 1805. Jean Baptiste Gariot opisao je svoj način izrade gipsanih modela i njihovo proširenje na zadnjoj strani, kako bi se napravio mehanizam za očuvanje odnosa gornjeg i donjeg gipsanog modela [4]. Artikulator Barn Door Hinge (Slika 2), koji je dizajnirao J. B. Gariot, imao je prednji vertikalni stoper. Prihvatao je centralnu relaciju vilica i pouzdano je reprodukovao [5].

\section{Artikulatori Hovarth i Ladmore}

Prva objavljena referenca najstarijih artikulatora sa mehaničkom osovinom je verovatno Ferherstova diskusija o Hovartovom i Ladmorovom artikulatoru 1830-ih godina. Ferherst opisuje ove i druge rane primere kao instrumente koji se sastoje od dva drvena ili metalna bloka ili ploče koji su povezani 
zajedno jednostavnom šarkom. Ovi artikulatori, kao i drugi iz tog vremena, sigurno su ličili na ono što se danas obično naziva „okludatorom“ [7].

\section{Tomas Evanov artikulator}

Jedan od najstarijih mehaničkih artikulatora osovine ilustrovan je i detaljno opisan u literaturi Tomasa V. Evana. U svom udžbeniku Čejpin A. Haris opisao je Tomas Evanov artikulator kao „vrlo jednostavan instrument“, kao i da je zadnje proširenje gipsanog modela i voska nepotrebno. Naglasio je da je najvažnija karakteristika bila da se vertikalna dimenzija može sačuvati ili izmeniti po potrebi. Nije poznato da li je Tomas Evan patentirao svoj artikulator. Prema Hausu, evidencija američke patentne kancelarije pre 1870 . godine može biti nepotpuna. U toj godini poverenik patenata potpuno je reorganizovao sistem vođenja evidencije i izdavanja patenata. Štaviše, negde između 1840. godine, kada su prvi patenti izdati, i 1870. godine, vatra je uništila mnoge originalne zapise patenata [7].

\section{Prvi američki patent artikulatora - Kameronov artikulator}

Prvi američki patent za artikulator dobio je Džejms Kameron 30. aprila 1840. Kameronov artikulator je bio jedinstven u dizajnu u poređenju sa drugim artikulatorima tipa osovine (Slika 3). Imao je prednje i zadnje funkcije vertikalnog podešavanja [7].

\section{Drugi američki patent artikulatora - Evenov artikulator}

Danijel T. Even je patentirao drugi artikulator (Slika 4). To je prvi artikulator koji je pokušao snimati pokrete donje vilice i prepoznavao kretanje mandibule napred i bočno. On je bio nazvan „Stomatološki vodič“. Nije zaživeo, a samim tim je i nestao sa scene. Bio je neuspešan jer je bio neprikladan i težak za korišćenje. [8]

\section{„Artikulatori sa fiksnim kondilarnim vođenjem“ i naredni unapređen}

Originalni Evensov artikulator, sa funkcijom horizontalne kretnje kondila, može se klasifikovati kao artikulator sa „fiksnim kondilarnim vođenjem “ $i$ on je najraniji od ove vrste. Još dva rana patentirana primera bila su Starr (1868) i Antes-Lewis $(1895,1900)$. Najpoznatiji artikulator u ovoj kategoriji bio je Bonwill (1858). Svi ovi artikulatori su bili prihvaćeni od strane stomatološke profesije. Zapravo, Bonwill je bio popularan mnogo godina. Ipak, nijedan nije imao principijelni napredak. Tek skoro 50 godina nakon što je Evens bio patentiran, Richmond S. Hayes je sproveo sledeći važan napredak, uvodeći kretanje kondila napred i nadole, kada je izdao svoj patent 1889 . god. za „fiksno kondilarno vođstvo“ [8].

\section{Prvi artikulator sa „podesivim kondilarnim vođstvom“}

Sledeći važan korak u dizajnu artikulatora dogodio se 1896. godine, kada je William E. Walker iz Pass Christiana, MS, dobio dva patenta za artikulatore sa podesivim kondilarnim vođstvom (Slika 5). Najranija verzija njegovog artikulatora, napravljenog oko 1895. godine, imala je fiksno kondilarno vođstvo. Iako je drugi model pokazivao podesive kondilarne pokrete, oni nisu mogli biti podešeni pojedinačno. Treći model Voker artikulatora bio je prvi koji uključuje pojedinačno podesive kondilarne vodiče, kao i podesive rotacione centre za bočno kretanje. Voker je patentirao ova zadnja dva modela sekvencijalno, nazvavši ih „Vokerovi fiziološki artikulatori“. Da bi izmerio put svakog kondila pojedinačno, Voker je dizajnirao aparat koji je nazvao „klinometer lica“ i postupak za njegovu upotrebu. Budući da je dizajniran da odredi ugao kondilarnih puteva na licu, može se smatrati prvom ekstraoralnom metodom za snimanje pokreta donje vilice, iako putevi nisu zapravo zapisani. Klinometar lica nikada nije bio patentiran [9].

\section{Izgled i rana upotreba incizalnih klinova i vodiča [10]}

Već 1840-ih neki oblik „vertikalnog zaustavljanja“ bio je česta komponenta mehaničkih artikulatora. Jasno je da su neki rani pronalazači prepoznali važnost očuvanja vertikalnog odnosa gipsanih modela u artikulatoru i dali tu mogućnost.

\section{Prvi artikulatori koji su patentirani sa povezanim incizalnim klinom i vodičem}

C. E. Luce iz Štutgarta u Nemačkoj je 28. novembra 1911. dobio prvi patent za artikulator sa incizalnim pinom i vodičem. Luce je bio jedan od prvih istraživača koji su opisali kretanje kondila nadole i napred (1889). Njegov artikulator je bio prvi koji je imao mogućnost „pisanja“ i kontrolu zadnjeg i incizalnog puta koji su bili funkcionalno generisani (Slika 6).

Drugi artikulator sa ovom karakteristikom je bio patentiran od strane Ernesta Eltnera iz Bazela u Švajcarskoj u julu 1912. godine. Eltnerov artikulator je predstavio horizontalni incizalni vodič sa podesivim zadnjim delom koji ograničava protuzivna kretanja. Inicijalni klin je imao oblik strelice.

Alfred Gysi je dobio patent za svoj „prilagodliivi“ artikulator u oktobru 1912. (Slika 7). Ovo je prvi njegov patent za američki artikulator. Iako je „prilagodljivi“ artikulator bio veoma napredan za to vreme, imao je samo fiksiran 45-stepeni klin za incizalno vođenje. Bez obzira na to, „prilagodljivo“ se smatralo suviše komplikovanim za prosečnog praktičara i on nikada nije postigao komercijalni uspeh. Gysi je koristio precizan dizajn incizalnog vođenja u svom „prostom“ artikulatoru, verziji „prosečne vrednosti“ prilagodljivog artikulatora.

Ray W. Burch of Hart, MI, u decembru 1913. godine primio je četvrti patent izdat za artikulator sa incizalnim klinom. Burch je prvi koji je primenio inovaciju prenošenja maksilarnih i mandibularnih obraznih lukova u artikulator. Obrazni lukovi su bili uređaji povezani sklopom slotova za kondile i podešavani su na licu pacijenta. Inicizalni klin je korišćen prosto za održavanje prednjeg vertikalnog položaja.

Nakon artikulatora Burcha, George B. Snow patentirao je „acme“ artikulator u novembru 1915. godine, koji je bio njegov treći patent, a prvi sa incizalnim klinom i vodičem. U najranijem modelu, protuzioni ugao sekutića podešen je zagrevanjem lema između komponenti identifikovanih brojevima 4 i 8 i pomeranjem stolića gore ili dole. Kasniji modeli su sadržali izmenjive stoliće i, na kraju, podesive stoliće.

David M. Shaw iz Elthama (Engleska) patentirao je artikulator u februaru 1916. Ovaj uređaj je u velikoj meri zanemaren, ali zaslužuje da se pomene zbog značajnog dizajna incizalnog 
klina, koji je služio da utiče na protuzivno i bočno kretanje sa zakrivljenim incizalnim klinom tipa strelice koji funkcioniše na krivini vođice.

U novembru 1916. Godine Rupert E. Hall je dobio svoj prvi patent za artikulator, uređaj koji je dobio nadimak „aligator“. „Aligator" je bio prvi artikulator koji je uključivao incizalni stolić sa podesivim bočnim krilima. Na drugom Holovom artikulatoru (mart 1917), u revidiranoj verziji „aligatora“, incizalni klin je bio dizajniran na stoliću koji je imao ugao od 45 stepeni.

\section{Holov „dentalni okludirajući ram“: prvi patentirani stolić incizalnog vođenja sa gotskim lukom}

Treći patent artikulatora Ruperta Hola, izdat za „Dentalni okludirajući ram“ (april 1917), bio je revolucionaran (Slika 8). To je bio arkon instrument koji se sastojao od podesivih, zakrivljenih kondilarnih puteva, uključujući postavku za Balkwill-Bennettov ugao, kao i mehanizam za podešavanje interkondilarne udaljenosti. Takođe je postojao horizontalni incizalni stolić sa podesivim bočnim krilima, kao i nova karakteristika - trouglasta vođica na svakom bočnom krilu koja se može postaviti tako da prati „gotski luk“.

\section{Maksilomandibularni instrument}

Dizajnirao ga je Džordž Monson 1918. godine i zasnovan je na teoriji sfere. Prema ovoj teoriji, koja je nastala iz koncepata Monsona i nemačkog anatomiste Grafa fon Špea, mandibularni zubi prelaze preko maksilarnih zuba kao na površinu sfere. Prosečni radijus sfere je četiri inča, ali je Monsonov instrument imao zavrtnje koji su mogli da variraju radijus instrumenta (Slika 9) [5].

\section{Stephen artikulator}

Stephen artikulator, razvijen 1921. godine, sličan je u dizajnu Gariotovom artikulatoru osovine iz 1805. godine, osim što ima fiksni nagib kondila i omogućava proizvoljno bočno kretanje. Zadnji zavrtnji drže gornji i donji deo artikulatora na fiksnoj vertikalnoj dimenziji [5].

\section{Artikulator Hanau model C i Kinoskop Hanau model M}

Rudolph L. Hanau, inženjer, uticao je na dr Rupert E. Halla da proučava dizajn artikulatora. Početkom 1921. razvio je model pod nazivom artikulator Hanau model C. Godine 1923. razvio je još jedan instrument, artikulator Hanau model M kinoskop (Slika 10). Ovaj zadnji je imao na svakoj strani dvostruke kondile. Unutrašnji delovi su služili u dve svrhe: (1) delovali su kao horizontalni vodiči kondila i (2) kao promenljivi centri rotacije kada se pomeraju unutra ili spolja. Benetov ugao se podešavao rotiranjem ekscentričnog konusa koji se nalazio na spoljnim polovima prema interkonondarnoj osi [5].

\section{Relator Homer}

Relator Homer je predstavio 1923. godine Joseph Homer. Bio je zasnovan na principu da se plastični materijal koristi za očuvanje pozicija artikulatora umesto mehaničkih vodiča. Tri čaše u donjem delu artikulatora ispunjene plastičnim materijalom bi snimile zapis i vodile tripodni gornji član u snimljene pozicije. Isti princip je korišćen kasnije u irskim duplukacionim i TMZ instrumentima [5].

\section{Artikulator Wadsworth}

Vodsvort je verovao u Monsonovu teoriju sfere, ali nije mogao prihvatiti bilateralnu simetriju kondila. U Vodsvortovom artikulatoru, razvijenom 1924. godine, gipsani modeli su montirani koristeći obrazni luk, a Vodsvortov T-dodatak je određivao treću referentnu tačku. Pregrada je korišćena za merenje udaljenosti od središnje tačke sekutića do centra kondila sa jedne strane. Ova dužina luka je prvo opisana od kondila, a zatim sa središnje tačke sekutića prema standardu koji se nalazio na gornjem delu instrumenta. Presek ovih lukova nalazio se na rotacionom centru za merenu stranu. Centar se koristio za dizajniranje sferične ravni okluzije. Imao je i podesivo interkondilarno rastojanje. Ovo merenje je određeno korišćenjem udaljenosti između kondilskih pokazivača na facijalnom luku minus 0,75 inča rastojanja kože na svakoj strani. Kondilarne staze instrumenta su bile blago zakrivljene [5].

\section{Hanau model H110}

Hanau model H110 je predstavio Hanau 1926. godine i dizajniran je prvenstveno za izradu totalne proteze. Obuhvatao je mehaničke proseke mnogih prethodnih koncepata. Imao je pojedinačno prilagodljive kondile u sagitalnoj i horinzontalnoj ravni [5]. Umesto da se koriste bočne snimljene pozicije, bočno podešavanje računato je korišćenjem formule, date u osnovi artikulatora:

$$
\mathrm{L}=\mathrm{H} / 8+12 \text {, gde je } \mathrm{H}=\text { horizontalni kondilarni ugao. }
$$

\section{Modifikovani Hanau H110 model}

Dizajniran je 1927. godine i uveo je stočić za incizalno vođenje. Originalni stočić incizalne vođice sa fiksnom krivinom mogao se pomerati samo kao jedinica i nije imao kalibracije za resetovanje. Poboljšani stočić se pojavio na artikulatorima Hanau od 1927. do 1972. godine i omogućio je prilagođavanje u tri dimenzije [5].

\section{Balanser Hagman}

Razvijen 1920-ih godina od strane H. C. Hagmana, balanser Hagman otvara i zatvara osovinu koja je u centru uspravne podrške, ali ne zahteva nikakav obrazni luk ili interokluzalni rekord za montažu. Središnji uređaj prenosi maksilarne i mandibularne otiske od pacijenta do artikulatora u jednom koraku. Takođe je zasnovan na sferičnoj teoriji okluzije. Mandibularni zubi su konstruisani prema Špeovoj krivi pomoću balansiranog okluzalnog vodiča, a maksilarni zubi su konstruisani tako da se uklapaju sa mandibularnim zubima [5].

\section{Artikulator Phillips Student}

Artikulator Phillips Student (Model C), ili pantografski artikulator, razvio je George P. Phillips 1926. godine (Slika 11). Ovaj artikulator je klasifikovan kao potpuno prilagodljiv, jer je njegov proizvođač tvrdio da će pratiti bilo koji grafički zapis. Phillips 
grafički zapisnik je dizajniran tako da u jednom koraku prati gotski luk (iglica) i nagib glenoidne fose. Artikulator je mogao mehanički reprodukovati kretanje grafičkog zapisnika pomoću dva vertikalna klina koji prate horizontalni nagib glenoidne fose i dva horizontalna klina koji su kopirali zapisnik klina [5].

\section{Tripodni instrument Stanbery}

Razvijen 1929. godine od strane C. J. Stanberya, ovaj artikulator je dizajniran bez osovine kako bi se olakšala reprodukcija bilo kojeg pozicijskog odnosa. Ne postoji mehanički ekvivalent ili kopija kondila. Artikulator reprodukuje pozicije a ne pokrete. Interokluzalni zapisi centralnog položaja kao i protruzionog, desnog i levog bočnog položaja koriste se za postavljanje tri pojedinačne kupole i otvore stativa, pri čemu se slotovi formiraju ravno do centralne pozicije [5].

\section{Artikulator House}

Artikulator House je razvio M. M. House početkom tridesetih godina. Ovaj artikulator koristi intraoralne položaje žvakanja ili druge položaje za podešavanje. Interkondilarni centri rotacije variraju bez pomeranja bočnih stubova koji podržavaju kondilarne elemente, pomoću kukica koje bi mogle kliziti duž interkondilarne trake. Bočno usmeravanje kondila kontrolisano je Benetovim vodičem, pričvršćenim bočno prema urezu za kondile. Stočić incizalnog vođenja mogao je kontrolisati horizontalne i vertikalne pokrete. Bočne ploče u stočiću incizalnog vodiča služile su kao zakrivljeni incizalni klin [5].

\section{Precizni koordinator}

Precizni koordinator je razvio W. H. Terrell početkom 1930-ih godina. To je artikulator arkon tipa koji ima krivolinijske vodiče kondila. Dvostruki parabolični brežuljak kontroliše vertikalno i horizontalno prednje vođenje. Incizalni klin je zakrivljen tako da omogućava promene u vertikalnoj dimenziji. Takođe postoji i sloboda kretanja u centralnom odnosu [5].

\section{Artikulator Hanau za krunice i mostove}

Njega je proizodio Hanau Inženjering Co. od 1934. do 1971. To je mali artikulator. Zadnji klin i brežuljak je mehanizam za navođenje koji se mogao postaviti tako da simulira radne i balansne ekskurzije od 15 stepeni. Mehanizam se mogao postaviti na $\mathrm{L}$ za nadoknade u levim kvadrantima, $\mathrm{R}$ za desne kvadrante ili Anterior za prednje nadoknade ili za izjednačavanje desnog i levog pomeranja. Njegove protuzivne kretnje bile su do 30 stepeni. Nije bio potreban obrazni luk [5].

\section{Filipsov okluzoskop}

Filipsov okluzoskop razvio je George P. Phillips 1938. godine. Gipsani model gornje vilice je montiran korišćenjem obraznog luka. Artikulator je bio prilagodljiv koriseći intraoralne ili ekstraoralne zapise. Donji član imao je dve podesive jedinice koje su predstavljale dva temporomandibularna zgloba. U okviru svake podesive jedinice postojao je kružni disk koji se mogao naginjati napred-nazad i bočno. Nije imao podesiv incizalni vodič. Inicizalni klin se nalazio na ravnom stočiću jer je Philips verovao da incizalni klin služi samo za sprečavanje zatvaranja i da ne bi trebalo da služi kao treći tempomandibularni zglob [5].

\section{ZAKLJUČAK}

Artikulatori su instrumenti koji pokušavaju da reprodukuju opseg kretanja vilica. Prvi dizajni instrumenta imali su za cilj kopirati anatomske odnose ili reprodukovati funkcionalne kretnje vilica. Sofisticiraniji artikulatori su razvijeni zahvaljujući novim saznanjima o anatomiji, mandibularnim pokretima i mehaničkim principima. Međutim, cilj je uvek bio isti: simulirati ili reprodukovati okluzalne odnose ekstraoralno. Bez obzira na to koliko je jednostavan ili komplikovan artikulator, ako ga operator ne koristi pravilno ili nema karakteristike za svrhu za koju se koristi, rezultati će biti razočaravajući [3]. Istorija artikulatora od 1940. godine nadalje biće objavljena u sledećem broju. 